\title{
WHAT WE DON'T SEE WHEN WE SEE COPYRIGHT AS PROPERTY
}

\author{
JESSICA LITMAN*
}

\begin{abstract}
For all of the rhetoric about the central place of authors in the copyright scheme, our copyright laws in fact give them little power and less money. Intermediaries own the copyrights, and are able to structure licenses so as to maximise their own revenue while shrinking their pay-outs to authors. Copyright scholars have tended to treat this point superficially, because - as lawyers - we take for granted that copyrights are property; property rights are freely alienable; and the grantee of a property right stands in the shoes of the original holder. I compare the 1710 Statute of Anne, which created statutory copyrights and consolidated them in the hands of publishers and printers, with the 1887 Dawes Act, which served a crucial function in the American divestment of Indian land. I draw from the stories of the two laws the same moral: Constituting something as a freely alienable property right will almost always lead to results mirroring or exacerbating disparities in wealth and bargaining power. The legal dogma surrounding property rights makes it easy for us not to notice.
\end{abstract}

Keywords: Copyright, Property, Authors' Rights, alienability, DawesAct.

\section{INTRODUCTION}

If you follow copyright law, it can't have escaped your attention that, in the US, the community of copyright law scholars has been deeply polarised for the past 25 years. Some of us see ourselves as advocates for the

\footnotetext{
* John F. Nickoll Professor of Law and Professor of Information, University of Michigan. Address for Correspondence: University of Michigan Law School, 625 S. State St., Ann Arbor, MI 48109, USA. Email: jdlitman@umich.edu. This essay is adapted from the 13th Annual University of Cambridge Centre for Intellectual Property and Information Law International Intellectual Property Lecture, delivered at Emmanuel College on 13 March 2018. I'm grateful to Jon Weinberg, Rebecca Giblin, Lionel Bentley, Gautam Hans, Pam Samuelson, Kirsten Carlson and Laura Harlow for their extremely helpful comments and suggestions. I first learned about the Dawes Act from Judge Betty Binns Fletcher, when she was working on her en banc opinion in Blackfeet Tribe of Indians v State of Montana, 729 F.2d 1192 (9th Cir. 1984), aff'd 471 U.S. 759 (1985). I was lucky to clerk for Judge Fletcher that year, and her continuing encouragement and support was immensely helpful in my career as a legal scholar. Judge Fletcher died in 2012 at the age of 89 - an active senior judge who was still carrying a full case load. According to the New York Times, she presided over a 9th Circuit hearing a week before her death. Douglas Martin, "Betty Binns Fletcher Dies at 89; Liberal Stalwart on the Bench", New York Times, 24 October 2012, available at <https://www.nytimes.com/2012/10/25/us/betty-binns-fletcher-liberalfederal-judge-dies-at- $89 . \mathrm{html}>$.
} 
undervalued interests of readers and other users; others argue that we need to increase the copyright protection we give to authors. It's gotten a little ugly. ${ }^{1}$ We've called one another bad names. ${ }^{2}$ Advocates for copyright owners have described scholars who defend the rights of users as hired guns paid by Google to write papers advancing its business interests. ${ }^{3}$ Some of us have stopped reading the work of scholars perceived to be on the other side. ${ }^{4}$

I believe (or at least I hope) that that whole sorry era is almost over, or will be over as soon as we forgive one another for all the nasty namecalling. As concrete reform proposals have emerged from the muck, it has become apparent that what was billed as a conflict between authors and users was never about that at all. Instead, what's been going on is a fight to the death among intermediaries. The highly publicised record label lawsuits against individual users of peer-to-peer file-sharing applications $^{5}$ turn out to have been a feint in a fight to hold Internet service providers liable for the activity of their subscribers. ${ }^{6}$ Bitter complaints about online consumer piracy $^{7}$ were largely a prelude to efforts by major

${ }^{1}$ See e.g. T. Reilly, "Copyright and a Synergistic Society" (2017) 18 Minnesota Journal of Law, Science \& Technology 575, at 591-609 (analysing scholarship arguing for limits on copyright and attributing the authors' views to "copyright envy").

2 See e.g. H. Hansen, D.O. Carson, E. Moglen, W. Seltzer and C. Sims, "Mickey Mice? Potential Ramifications of Eldred v. Ashcroft" (2003) 13 Fordham Intell.Prop.Media \& Ent.L.J 771, at 787 ("the anti-copyright professors"); H. Horbaczewski, "No Silver Lining for the Emperor's New Clothes: Golan and the Traditional Contours of Copyright" (2012) 59 J. Copyright Soc'y U.S.A. 865 , at 865 ("scholars that viewed the copyright law as a constitutional abomination"); I.F. Koenigsberg, "The Fifth Annual Christopher Meyer Memorial Lecture: Humpty Dumpty in Copyright Land" (2004) 51 J. Copyright Soc'y U.S.A. 677, at 680 ("enemies of copyright"); M.A. Lemley, "Faith-Based Intellectual Property" (2015) 62 UCLA Law Review 1328, at 1343 ("the IP faithful"); Reilly, "Copyright and a Synergistic Society", p. 625 ("anti-author proponents"); ibid., at p. 626 ("if one reads professorial accounts such as these closely, one can also detect the perfidious underlying presence of 'copyright envy"'); P. Samuelson, "The Copyright Grab", WIRED, 1 January 1996, available at $<$ https://www.wired.com/1996/01/white-paper/> ("copyright maximalists"); P. Schwartz and W. M. Treanor, "Essay, Eldred and Lochner: Copyright Term Extension and Intellectual Property as Constitutional Property" (2003) 112 Yale L.J. 2331, at 2331 ("the IP Restrictors"). Cf. K. McLeod, Freedom of Expression (New York 2005), 65 (referring to copyright bullies as "overzealous copyright bozos").

3 See B. Mullins and J. Nickas, "Inside Google's Academic Influence Campaign", Wall Street Journal, 14 July 2017 , available at $<$ https://www.wsj.com/articles/paying-professors-inside-googles-academicinfluence-campaign-1499785286>; A. Rogers, "Google's Academic Influence Campaign: It's Complicated", WIRED, 14 July 2017, available at <https:/www.wired.com/story/googles-academicinfluence-campaign-its-complicated $/>$.

4 See J. Litman, "War \& Peace: The 34th Annual Donald C Brace Lecture" (2006) 53 J. Copyright Soc'y U.S.A. 1; J. Litman, "The Politics of Intellectual Property" (2009) 27 Cardozo Arts \& Ent.L.J. 313.

5 See e.g. Capitol Records v Thomas-Rasset, 692 F.3d 899 (8th Cir. 2012); Sony BMG Music Entertainment $v$ Tenenbaum, 660 F.3d 487 (1st Cir. 2011).

${ }^{6}$ E.g. BMG Rights Management v Cox Communications, 881 F.3d 293 (4th Cir. 2018); EMI Christian Music v MP3Tunes, 844 F.3d 79 (2d Cir. 2016). See C. Doctorow, Information Doesn't Want to Be Free: Laws for the Internet Age (San Francisco 2014), 80-89.

${ }^{7}$ See e.g. Privacy and Piracy: The Paradox of Illegal File Sharing on Peer-to-Peer Networks and the Impact of Technology on the Entertainment Industry, Hearing Before the Permanent Subcommittee on Investigations of the Senate Committee on Government Affairs, 108th Congress (30 September 2003), 19-20 (testimony of L.L. Cool, recording artist); Promoting Investment and Protecting Commerce Online: Legitimate Sites v. Para-sites, Hearing Before the Subcommittee On Intellectual Property of the House Judiciary Committee, 112th Congress (14 March 2011), 61-62 (testimony of Frederick Huntsberry, Paramount Pictures). 
copyright owners to narrow the safe harbours for online services. ${ }^{8}$ Legacy intermediaries (by which I mean publishers, record labels, and movie studios) are fighting with new-fangled intermediaries (that is, online service providers, platforms, and digital delivery businesses); what they are really fighting about is who gets to eat the biggest piece of pie. ${ }^{9}$

Copyright scholars can safely leave them to work it out without our help. If the core question in that dispute is whether the law ought to favour publishers over platforms or vice versa, the answer is unlikely to significantly change the copyright ecosystem. Neither side has much of a claim to the moral high ground. ${ }^{10}$ The players on both sides are large, well-financed businesses with lots of lawyers in harness, so they don't particularly need the assistance of legal scholarship. That debate is less compelling from a theoretical or policy perspective than many other problems the copyright system faces. If the distribution of goodies among old-fangled and new-fangled intermediaries won't have much impact on decisions surrounding the balance the law should strike among writers and readers, many scholars will lose interest in this particular conflict. So, after we get our feet extracted from all the mud we've thrown at each other, I expect that the community of copyright scholars will move on to more intriguing issues.

In this essay, I hope to do two things. First, I'd like to focus attention on an important issue that should have been central to our prior debates, but somehow wasn't: For all of the rhetoric about the central place of authors in the copyright scheme, our copyright laws in fact give them little power and less money. If a legal regime purportedly designed for the benefit of authors systematically short-changes them, why does that happen and what options might we have to respond? Copyright scholars mention this problem often, ${ }^{11}$ but have only rarely given it sustained attention.

${ }^{8}$ See e.g. United States Copyright Office: Section 512 Public Roundtable, 2 May 2016, available at $<$ https://www.copyright.gov/policy/section512/public-roundtable/transcript_05-02-2016.pdf $>$.

${ }^{9}$ See e.g. R. Levine, Free Ride: How the Internet is Destroying the Culture Business and How the Culture Business Can Fight Back (London 2011); J. Taplin, Move Fast and Break Things: How Facebook, Google, and Amazon Cornered Culture and Undermined Democracy (New York 2017); G. Pessach, "Deconstructing Disintermediation: A Skeptical Copyright Perspective" (2013) 31 Cardozo Arts \& Ent.L.J. 833; M. Rasenberger and C. Pepe, "Copyright Enforcement and Online File Hosting Services: Have Courts Struck the Proper Balance" (2012) 59 J. Copyright Soc'y U.S.A. 627. Compare S.E. Siwek, Copyright Industries in the US Economy: 2016 Report (December 2016), available at <http://www.iipawebsite.com/pdf/2016CpyrtRptFull.PDF>, with Computer and Communications Industry Association, Fair Use Industries in the U.S. Economy: Economic Contributions of Industries Relying on Fair Use (2017), available at $<$ http://www.ccianet.org/wp-content/uploads/2017/06/Fair-Use-in-the-U.S.-Economy-2017.pdf>; US Copyright Office, Section 512 Study (2017), available at $<$ https://www.copyright.gov/policy/section512/> (public comments and transcripts of public roundtables).

${ }^{10}$ See J.C. Ginsburg, "The Place of the Author in Copyright" in R.L. Okediji (ed.), Copyright Law in an Age of Exceptions and Limitations (New York 2017), 60, 66-68.

11 See e.g. W. Patry, Moral Panics and the Copyright Wars (Oxford 2009), 117-19; D. Gervais, "UserGenerated Content and Music File-Sharing: A Look at Some of the More Interesting Aspects of Bill C-32" in M. Geist (ed.), From "Radical Extremism" to "Balanced Copyright": Canadian Copyright And The Digital Agenda (Toronto 2010 ), 447, 450; R. Giblin, "Reimagining Copyright's Duration" 
Second, I'll try to offer an answer to the question why we've devoted so little ink to the paltry nature of authors' real-world copyright benefits. This issue, after all, is deeply important on both a practical and theoretical level, so why don't we write about it more? At least part of the answer, I'll suggest, lies in the ways that we, as lawyers, think about property rights.

\section{DisEMPOWERED AuthorS}

Let me acknowledge my priors. Twenty-first-century copyright law is a complex system with a bunch of interlocking and sometimes inconsistent purposes, but I believe that the most important of those purposes are these: first, copyright law should encourage authors to create and widely disseminate works of authorship; second, it should give them meaningful opportunities to earn money from doing so; and, third, copyright law should encourage readers, listeners, viewers, and other users to encounter, enjoy and learn from those works of authorship. ${ }^{12}$ There are other purposes, but they're subsidiary. To hijack a turn of phrase popularised by Amazon.com's vice president Russ Grandinetti, the only essential players in the copyright system are the author and the audience. ${ }^{13}$

Of course, the copyright system needs intermediaries to convey the works of authorship to their audiences and to channel the revenues flowing from the enjoyment of those works back to authors, but we can, and I think should, be agnostic as to whether the law should favour any of the competing intermediaries over the others. The most important consideration is how well they accomplish their tasks of disseminating works to audiences and paying money to authors. ${ }^{14}$

So, let's look at how they're doing at those tasks. How well is the current global copyright system working out for authors and for readers? I've spent much of my career arguing that the copyright interests of readers and other consumers are receiving too little attention. ${ }^{15}$ The problems the copyright

in R. Giblin and K. Weatherall (eds.), What If We Could Reimagine Copyright? (2017) 177, 193-96; Ginsburg, "The Place of the Author in Copyright"; P.B. Hugenholtz, "The Great Copyright Robbery: Rights Allocation in a Digital Environment" (2000), available at $<$ https://www.ivir.nl/publicaties/download/thegreatcopyrightrobbery.pdf >; M. Van Houweling, "Authors vs Owners" (2016) 54 Hous.L.R. 371; M. Van Houweling, "Distributive Values in Copyright" (2004) 83 Tex.L.Rev. 1535.

12 J. Litman, "Real Copyright Reform" (2010) 96 Iowa L.Rev. 1. See also e.g. Doctorow, Information Doesn't Want to Be Free, pp. 153-54.

13 See D. Streatfield, "Amazon Signs Up Authors, Writing Publishers Out of Deal", New York Times, 17 October 2011, p. A1 (quoting Grandinetti as having said: "The only really necessary people in the publishing process now are the writer and reader").

14 Many intermediaries, whether they are book publishers, online marketplaces or social media platforms, reasonably view their efforts at market analysis, strategy and design to involve great creativity. Comparable creativity is, of course, often required to sell products, like wheelbarrows or hot sauce, that are not works of authorship. The fact that intermediaries make creative and valuable contributions to the copyright ecosystem doesn't, without more, make them its indispensable beneficiaries.

15 See e.g. J. Litman, “Copyright Noncompliance (Or Why we Can't 'Just Say Yes' to Licensing)” (1997) 29 N.Y.U. Journal of International Law \& Policy 237; J. Litman, "The Exclusive Right to Read" (1994) 13 Cardozo Arts \& Ent.L.J. 29; J. Litman, "Lawful Personal Use” (2007) 85 Tex.L.Rev. 1871. 
law poses for readers haven't evaporated. For one thing, at least in the US, readers are paying for access to the works they encounter by giving up massive chunks of personal privacy. ${ }^{16}$ US policymakers are beginning to appreciate the risks of that approach, but it may already be too late to mend them. For another, many copyright owners have succeeded, at least so far, in their efforts to nullify the legal rights that the copyright law gives to users, by purporting to bind consumers to overreaching end user license agreements. ${ }^{17}$ I'm concerned that that will end up severely undermining the copyright system in the long term. Still, even with those problems, to the extent that one goal of copyright is to give members of the public many opportunities to enjoy a large variety of different works, in different formats and at different price points, the current system is fabulously successful.

The situation for authors, on the other hand, is more depressing. The copyright system, in truth, has never been very good at either giving authors their choice of myriad channels for distributing their works to the public, or enabling them to earn meaningful amounts of money from doing so. ${ }^{18}$ If an author's goals are to communicate her works to their best audience and to earn an income from doing so, her choices end up being narrowly limited. Even if she succeeds in disseminating her work through the most suitable channel, she needs to accept that the intermediary who operates that channel will likely both control the distribution of her works and keep most of the money those works earn. ${ }^{19}$

In the eighteenth, nineteenth and twentieth centuries, this bargain probably seemed pretty reasonable. Paper was expensive. ${ }^{20}$ Mass distribution required paper, along with printing presses, bookstores, warehouses, trucks, movie cameras and movie theatres, broadcast towers and communications satellites - required, in other words, a significant capital investment. ${ }^{21}$ It made sense in that context to expect that as the revenues from works of authorship flowed from users to authors, most of the money would be diverted along the way to pay for expensive reproduction and distribution solutions.

16 See e.g. J.M. Newman, "The Myth of Free" (2018) 86 G.W. Law Rev. 513, at 551-55; G.A. Fowler, "Your Data Is Way More Exposed than You Think", Wall Street Journal, 24 May 2017, available at $<$ https://www.wsj.com/articles/your-data-is-way-more-exposed-than-you-realize-1495657390>;

S. Schechner and N. Kostove, "Google and Facebook Likely to Benefit from Europe's Privacy Crackdown", Wall Street Journal, 23 April 2017, available at $<$ https://www.wsj.com/articles/how-europes-new-privacy-rules-favor-google-and-facebook-1524536324>.

17 See A. Perzanowski and J. Schultz, The End of Ownership (Cambridge, MA 2016), 15-101; M.J. Radin, Boilerplate (Princeton 2013), 33-51, 168-76; see e.g. L. Hyde, Common as Air: Revolution, Art, and Ownership (New York 2010), 66-68.

18 See e.g. Doctorow, Information Doesn't Want to Be Free, pp. xxii-xxv.

19 See Litman, "Real Copyright Reform", pp. 8-12.

20 See M.A. Carroll, "Whose Music Is it Anyway? How We Came to View Musical Expression as a Form of Property" (2004) 72 U.Cin.L.Rev. 1405, at 1471.

21 See e.g. J. Litman, "Sharing and Stealing" (2004) 26 Hastings Communication \& Entertainment Law Journal 1 , at 2 . 
In the twenty-first century, that explanation doesn't seem so reasonable. At least some popular reproduction and distribution alternatives are much less expensive than the older sorts. ${ }^{22}$ Digital reproduction, digital downloads and online streaming can be downright cheap - the fact that anyone can afford to do it is said to be a primary driver of increasing consumer piracy. ${ }^{23}$ By all accounts, moreover, the money attributable to the distribution and enjoyment of works of authorship is at an all-time high. ${ }^{24}$ Yet creators report that they are being paid much less than they used to be paid. ${ }^{25}$

Some of the explanation for that might relate to the winner-take-all structure of many of the copyright intensive industries. J.K. Rowling, ${ }^{26}$ Damien Hirst, ${ }^{27}$ Beyoncé Knowles, ${ }^{28}$ George Lucas $^{29}$ and Lin Manual Miranda ${ }^{30}$ have earned a bunch of money from their works of authorship. The majority of creators, in contrast, regularly face the choice of living perilously close to

22 See e.g. Hyde, Common as Air, pp. 64-65; M.A. Lemley, "IP in a World Without Scarcity" (2015) 90 N.Y.U.L.Rev. 460, at 482-94.

23 See e.g. O. Kerr, "A Lukewarm Defense of the Digital Millennium Copyright Act" in A. Thierer and C. W. Crews (eds.), CopyFights: The Future of Intellectual Property in the Information Age (Washington 2002), 163, 165-67; F. Von Lohmann, "Measuring the Digital Millennium Copyright Act Against the Darknet: Implications for the Regulation of Technological Protection Measures" (2004) 24 Loy.L.A. Ent.L.Rev. 635, at 638-43.

24 See e.g. J.P. Friedlander, "RIAA Year-End Music Industry Revenue Report", 22 March 2018, available at $\quad<\mathrm{http}: / /$ www.riaa.com/wp-content/uploads/2018/03/RIAA-Year-End-2017-News-and-Notes.pdf>; Siwek, "Copyright Industries in the US Economy"; A. Szamosszegi and M.A. McCleary, "Fair Use in the US Economy" (2017), available at <https://www.ccianet.org/wp-content/uploads/2017/06/FairUse-in-the-U.S.-Economy-2017.pdf>. Reports focusing on particular income streams earned by some legacy intermediaries don't count all of the revenue that new-fangled intermediaries are collecting as a result of the online dissemination of works of authorship. See e.g. Statista, "Dossier: Film Industry in the U.S." (2018), available at <https://www.statista.com/study/11472/film-industry-in-the-unitedstates-statista-dossier/>. That money is of course part of the total that should be available for author compensation. Moreover, those industry sector-specific reports indicate that legacy intermediaries are earning impressive profits, despite the large amounts of money paid to platforms and other new-fangled intermediaries. See e.g. ibid.; Friedlander, "RIAA Year-End Music Industry Revenue Report", p. 1.

${ }^{25}$ See e.g. K. Cowdray, "ALCS Survey Finds 15\% Drop in Average Author Earnings since 2013", The Bookseller, 27 June 2018, available at $<\mathrm{https}$ ://www.thebookseller.com/news/alcs-reveals-averageauthor-earnings-even-lower-four-years-ago-818891>; D. Dupont, "Composer Maria Schneider Warns Students about the Future of the Music Industry", Bowling Green Independent News, 31 March 2018, available at <http://bgindependentmedia.org/composer-maria-schneider-warns-students-aboutthe-future-of-the-music-industry/>; M. Harris, "How Much Is a Word Worth?", Medium, 16 April 2018, available at <https://medium.com/s/story/how-much-is-a-word-worth-7fcd131a341c >; D. Preston, "Why Is it So Goddamned Hard to Make a Living as a Writer Today?", Authors Guild Bulletin 63, Summer 2017.

${ }^{26}$ See J.B. Stewart, "In the Chamber of Secrets: J.K. Rowling's Net Worth", New York Times, 24 November 2016, available at <https://www.nytimes.com/2016/11/24/business/in-the-chamber-ofsecrets-jk-rowlings-net-worth.html $>$.

27 See E. Kinsella, "Damien Hirst and Anish Kapoor Land on UK Rich List (Again)", Artnet News, 8 May 2017, available at <https://news.artnet.com/art-world/artists-on-sunday-times-rich-list-952055>.

28 See Z. O'Malley Greenburg, "The World's Highest Paid Women in Music 2017”, Forbes, 20 November 2017, available at $<$ https://www.forbes.com/sites/zackomalleygreenburg/2017/11/20/the-worlds-highest-paid-women-in-music-2017/>.

29 See Z. O'Malley Greenburg, “America's Wealthiest Celebrities: The Top 10 by Net Worth”, Forbes, 18 December 2017, available at <https://www.forbes.com/sites/zackomalleygreenburg/2017/12/18/americas-wealthiest-celebrities-2017-the-top-ten-by-net-worth/>.

${ }^{30}$ See M. Paulson and D. Gelles, "Hamilton, Inc.: The Path to a Billion-Dollar Broadway Show", 8 June 2016, available at <https://www.nytimes.com/2016/06/12/theater/hamilton-inc-the-path-to-a-billiondollar-show.html>. 
the poverty line or working at a day job to support their families. ${ }^{31}$ But that isn't a new thing. ${ }^{32}$ If creators are earning even less than they used to, there are other factors at work.

This is a complicated problem with multiple causes, but one of the causes is that many of the intermediaries in our story have recently figured out ways to earn more but pay authors less. I alluded earlier to the conflict between old-fangled and new-fangled intermediaries. The legacy intermediaries seem to be incensed that service providers and platforms are collecting a large share of the revenues earned by copyrighted works. They've invented a catch phrase, the "value gap", to describe their complaint, which is that the new-fangled intermediaries have too much bargaining power and are able to use that bargaining power to negotiate lower license fees than the legacy intermediaries believe that they should pay. ${ }^{33}$ Publishers, record labels, and motion picture studios argue that lawmakers should change the law to tilt the playing field in their favour, so that they can bargain for higher fees. ${ }^{34}$ Meanwhile, though, they are making up for what they believe are pitifully inadequate licensing fees by structuring the licensing deals to minimise their own obligation to pay royalties to creators. ${ }^{35}$ If Spotify or YouTube pays copyright owners for the use of music, for example, by giving music publishers and record labels an equity stake in the company, or by paying an annual up-front blanket license fee, none of that money needs to be passed on to composers or musicians. ${ }^{36}$

31 See e.g. T. London and B. Pesner, Outrageous Fortune: The Life and Times of the New American Play (New York 2009), 50-96; R. Deahl, "New Guild Survey Reveals Majority of Authors Earn Below Poverty Line", Publishers Weekly, 11 September 2015, available at <https://www.publishersweekly. $\mathrm{com} / \mathrm{pw} /$ by-topic/industry-news/publisher-news/article/68008-new-guild-survey-reveals-majority-ofauthors-earn-below-poverty-line.html>; J. Gibson, P. Johnson and G. Dimita, "The Business of Being an Author: A Survey of Authors' Earnings and Contracts", April 2015, available at $<$ https://orca.cf.ac.uk/ 72431/1/Final\%20Report\%20-\%20For\%20Web\%20Publication.pdf>; M. Kretschmer, "Does Copyright Law Matter? An Empirical Analysis of Creators Earnings", 21 May 2012, available at SSRN: <https:// ssrn.com/abstract=2063735>; M. Kretschmer, S. Singh, L. Bently and E. Cooper, "2011 Copyright Contracts and Earnings of Visual Creators: A Survey of 5800 British Designers, Fine Artists, Illustrators and Photographers", 2011, available at < https://core.ac.uk/download/pdf/4899875.pdf >.

32 See e.g. H. Finklestein, "The Copyright Law: A Reappraisal" (1956) 104 U.Pa.L.Rev. 1025, at 1051; M. O'Rourke, "Bargaining in the Shadow of Copyright Law After Tasini" (2003) 53 Case W.Res.L. Rev. 605, at 613-14.

33 See G. Peoples, "War of Words: Labels and Trade Groups Target YouTube's 'Value Gap"”, Billboard, 13 April 2016, available at <https://www.billboard.com/articles/business/7333110/war-of-words-labelstrade-groups-youtube-value-gap $>$; see e.g. Joint Comments of the American Association of Independent Music et. al., In re: Section 512 Study, 31 March 2016, available at $<$ https://www.riaa.com/wp-content/ uploads/2016/03/Music-Community-Submission-in-re-DMCA-512-FINAL-7559445.pdf>; International Federation of the Phonographic Industry, "Europe's Creators, Cultural and Creative Industries' Call to the European Council: Secure the Aims of the Proposed Copyright Directive in the DSM", 12 April 2018, available at <http://www.ifpi.org/downloads/EU_Creators_Cultural_and_Creative_ Industries_Call_to_European_Council.pdf>.

34 See e.g. IFPI, "Rewarding Creativity: Fixing the Value Gap", available at $<\mathrm{http}$ //www.ifpi.org/value_gap.php> (visited 19 April 2018).

35 See e.g. K. Garcia, "Private Copyright Reform" (2013) 20 Mich. Telecom. \& Technology Law Review 1 , at 22-23, 27-29.

36 See e.g. 19 Recordings $v$ Sony Music Entertainment, No. 14-CV-1056 (SDNY filed 24 June 2015); Z. O’Malley Greenburg, "Revenge of the Record Labels: How the Majors Renewed Their Grip on Music", Forbes, 15 April 2015, available at <https://www.forbes.com/sites/zackomalleygreenburg/ 
In a similar vein, publishers have reinterpreted extant contracts and redrafted new contracts to reduce the royalty rates for digital distribution of the works they control. In standard $20^{\text {th }}$ century book and music publishing and recording contracts, authors were paid a small percentage of revenue for the manufacture and distribution of hard copies and a larger share of the income from licensing the work to another business. ${ }^{37}$ That made sense; the smaller royalty for hard copies reflected the expense of manufacturing and distributing the copies, neither of which were implicated by licensing deals. When publishers and record labels licensed works to music and eBook distribution services to enable the services to make the works available for paid digital downloads, though, they insisted that they need only pay the lower royalty rate designated for the sale of hard copies, and that's the rate that they paid. ${ }^{38}$

On one level, none of this should surprise us. Of course, the people who control the terms and conditions of use will structure those terms and conditions in ways that best advance their own interests. What I find notable is how little attention these recent moves have attracted from legal scholars. Indeed, even though we are all likely aware of these developments (because we live in the world), if you read most of what American copyright scholars have written about copyright revision, you'd conclude we don't think that these developments should worry us as much as other problems. ${ }^{39}$

2015/04/15/revenge-of-the-record-labels-how-the-majors-renewed-their-grip-on-music $>. \quad$ In $\quad 2016$, major record labels in the US announced that musicians would eventually be paid a share of the profits that the labels earned from selling their equity stakes in Spotify, but have been slow to disclose specifics. Z. O'Malley Greenburg, "Spotify Goes Public at \$30 Billion: When Will Artists See Any of That?", Forbes, 3 April 2018, available at <https://www.forbes.com/sites/zackomalleygreenburg/2018/ 04/03/spotify-ipo-goes-public-at-30-billion-when-will-artists-see-any-of-that $>$ Sony Music Entertainment sold half of its equity stake in Spotify in April of 2018, earning an estimated \$761 million. In June of 2018, the company promised that it would pass along a portion of the proceeds from the sale to artists and independent labels beginning in August. See M. Newman, "Sony Music Entertainment to Start Paying Indie Artists and Labels Spotify Sale Proceeds as Early as August", Billboard, 14 June 2018, available at <https:/www.billboard.com/articles/business/8461117/sonymusic-canada-spotify-pay-indie-artists-labels $>$. Warner Music sold $75 \%$ of its stake in Spotify in May of 2018, but, as of this writing, has not revealed its plans for sharing the money with creators.

37 See e.g. R. Curtis, How to Be Your Own Literary Agent: An Insider's Guide to Getting Your Book Published (New York 2003), 62-76, 295-97; N. Aragon, "Note: Calculating Artists' Royalties: An Analysis of the Courts' Dualistic Interpretations of Recording Contracts Negotiated in a Pre-Digital Age" (2017) 2017 Cardozo Law Review De Novo 180, at 184-88; L. Blake and D.K. Stuart, "Analysis of a Recording Contract" in M. Halloran (ed.), The Musician's Business and Legal Guide (Upper Saddle River 2008), 282, 312-13.

38 See e.g. FBT Productions v Aftermath Records, 621 F.3d 958 (9th Cir 2010); Tavares v Capitol Records, LLC, 2013 U.S. Dist. LEXIS 34317 (ND Cal. 2013); cf. Keiler v Harlequin Enters., 751 F.3d 64 (2d Cir. 2013) (book publisher evaded 50\% license royalty by sublicensing to its own subsidiary for an artificially low price). There's been some litigation over this, with mixed results. One court concluded that the plain language of particular contracts obliges record labels to pay the larger licensing royalty for digital downloads. FBT Productions, 621 F.3d 958 (9th Cir 2010), 964-66. A different court held that the plain language of an essentially similar contract supports the argument that royalties for digital download licenses should be the same as royalties for the sale of hard copies. Malmsteen $v$ Universal Music Group, 940 F. Supp. 2D 123, 132-33 (SDNY 2013).

39 This assertion is controversial. Indeed, some scholars will find it offensive. Everyone who writes copyright scholarship views her work as pro-creator and pro-creativity, and believes that her proposals will improve the way the system works for the ultimate benefit of creators, however defined. I'm not suggesting that scholars have not cared about creators, or have failed to produce proposals designed to 
European scholars have recently paid somewhat more attention to this collection of issues as part of a contentious effort to revise the European Directive on Copyright in the Digital Single Market, ${ }^{40}$ and their reports have been dismaying. Real-world creators encounter significant obstacles to enjoying the rights and receiving the compensation that the law in theory affords them. ${ }^{41}$ Yet proposed solutions seem both modest and unlikely to effect significant improvement. ${ }^{42}$ Meanwhile, even those small correctives seem as if they would be unthinkable additions to current American efforts at copyright reform.

If all of us can see these issues, at least in broad outline, and if at least some of us believe that these problems undermine the value and legitimacy of the copyright system, why have we not come up with better suggestions for addressing it?

One possibility is that many of us have concluded that it's hopeless: the problem seems insoluble. Copyright intermediaries have too many opportunities to take advantage of creators and too few reasons to refrain from exploiting them. Over the past three hundred years, copyright laws have incorporated a variety of provisions intended to protect creators from overreaching intermediaries; none of them has been particularly effective. In the US, our copyright history is teeming with court decisions that gutted statutory safeguards for authors' rights.

Although US copyright law has always required that transfers of copyright be made only by a signed writing, ${ }^{43}$ nineteenth-century publishers

benefit them. I'm urging, rather, that our scholarship has paid too little attention the practical obstacles many creators face in taking advantage of the rights conferred by copyright law on copyright owners. Almost all of us (and I don't exclude myself) have failed to examine the ways that recent copyright practices and proposals give creators even less money and control than past practices and proposals. To the extent that we have an imperfect understanding of the mechanics of the copyright system in practice, our ideas for fixing it are likely to fall short.

40 See European Commission, "Proposal for a Directive of the European Parliament and of the Council on Copyright in the Digital Single Market", 14 September 2016, available at $<$ http://ec.europa.eu/transparency/regdoc/rep/1/2016/EN/1-2016-593-EN-F1-1.PDF>. Most of the controversy centres on whether proposals to rebalance the law to provide more robust rights to publishers and impose more onerous obligations on platforms are good or bad policy. See e.g. P. Samuelson, "Legally Speaking: The EU's Controversial Digital Single Market Directive", 61 Communications of the ACM, forthcoming November 2018; "Google Criticized for Push Against EU Copyright Reform", Financial Times, 26 June 2018, available at <https:/www.ft.com/content/a8031d7a-78a0-11e8-bc55-50daf11b720d >; M. Banks, "MEPs Rally against Planned EU Copyright Reform", The Parliament, 8 June 2018, available at $<$ https://www.theparliamentmagazine.eu/articles/news/meps-rally-against-planned-eu-copyrightreform >; K.G. Orphanides, "The EU's Bizarre War on Memes is Totally Unwinnable”, Wired, 18 June 2018, available at $<$ http://www.wired.co.uk/article/eu-meme-war-article-13-regulation $>$.

41 See e.g. L. Bently, "Between a Rock and a Hard Place: The Problems Facing Freelance Creators in the UK Media Marketplace, A Briefing Document on Behalf of the Creators Rights Alliance", 29 June 2009, available at $<$ http://www.creatorsrights.org.uk/media/between.pdf $>$; Gibson, "The Business of Being an Author"; Kretschmer, "Does Copyright Law Matter?".

42 Chapter 3 of the current draft EU directive would oblige member states to ensure that authors and performers receive regular reports on the revenue generated by their works and the remuneration to which they are entitled, and to provide mechanisms for authors and performers to request additional remuneration when the revenues earned from their works are grossly disproportionate to the revenues anticipated when a copyright assignment or licensing agreement was negotiated. See note 40 above.

43 See e.g. Copyright Act of 1790, $\S 2,1$ Stat. 124, 1st Cong. 2d Sess. (1790); Act. of February 3, 1831, $\S 6,7,21$ stCong. 2d Sess. (1831); Rev. Stat. $\S \S 4964,4965$. 
persuaded courts that that prerequisite did not limit their ability to secure ownership of the copyrights in works that had not yeen published and registered. ${ }^{44}$ The copyright renewal term was intended to enable an author who had assigned her copyright in the first term to renegotiate the terms of any licenses or assignments. ${ }^{45}$ In 1943, however, music publisher M. Witmark \& Sons persuaded a divided Supreme Court that an assignment of the renewal term during the initial term was enforceable against the author. ${ }^{46}$ In the 1976 Copyright Act, Congress replaced the renewal term with an inalienable right to terminate any assignment, grant, or license, and provided expressly that an author was entitled to terminate "notwithstanding any agreement to the contrary". ${ }^{47}$ The House Report explained that, in contrast to the ownership of the renewal term, "the right to take this action cannot be waived in advance or contracted away". ${ }^{48}$ Yet, assignees of copyright have devised strategies for undermining the supposed inalienable termination right, and have largely succeeded in persuading courts of their effectiveness. ${ }^{49}$

44 See e.g. Parton v Prang, 18 F. Cas. 1273, 1278 (C.C.D. Mass. 1872); Lawrence v Dana, 15 F. Cas. 26 (C.C.D. Mass 1869); Pulte v Derby, 20 F. Cas. 51 (C.C. D. Ohio 1852). See generally J. Litman, "What Notice Did" (2016) 96 B.U.L.Rev. 717, at 724-31.

45 H.R. Rep. No. 2222, 60th Cong. 14 (1909). See J.J. Guinan, Jr., "Duration of Copyright: Study No. 30" (1957), 77-79, reprinted in Copyright Society of the USA, Studies on Copyright, vol. 1 (1963), 495-97; B.A. Ringer, "Renewal of Copyright: Study No. 31" (1960), 121-22, reprinted in Copyright Society of the USA, Studies on Copyright, vol. 2 (1963), 503, 517-18.

46 Fred Fisher Music Co. v M. Witmark \& Sons, 318 U.S. 643 (1943). The majority rejected the argument that the statute should be construed to preserve the author's opportunity to renegotiate the terms of licenses or assignments:

The policy of the copyright law, we are told, is to protect the author - if need be, from himself - and a construction under which the author is powerless to assign his renewal interest furthers this policy. We are asked to recognize that authors are congenitally irresponsible, that frequently they are so sorely pressed for funds that they are willing to sell their work for a mere pittance, and therefore assignments made by them should not be upheld...

It is not for courts to judge whether the interests of authors clearly lie upon one side of this question rather than the other. If an author cannot make an effective assignment of his renewal, it may be worthless to him when he is most in need. Nobody would pay an author for something he cannot sell. We cannot draw a principle of law from the familiar stories of garret-poverty of some men of literary genius. Even if we could do so, we cannot say that such men would regard with favour a rule of law preventing them from realizing on their assets when they are most in need of funds. ...

We conclude, therefore, that the Copyright Act of 1909 does not nullify agreements by authors to assign their renewal interests (ibid., at 656-57).

4717 USC § 203(a)(5). See generally R.A. Reese, "Termination Formalities and Notice" (2016) 96 B.U.L. Rev. 895; Authors Alliance, "Termination of Transfers" (2017), available at $<$ https://www.authorsalliance.org/wp-content/uploads/2018/03/20180315-ToT-Templates.pdf>.

48 H.R. Rep. No. 1476, 94th Cong. 125 (1976).

49 E.g. Larson v Warner Brothers, 640 Fed. Appx. (9th Cir. 2016); Marvel Characters v Kirby, 726 F. $3 d$ 119 (2d Cir. 2013); DC Comics v Pacific Pictures Corp., 545 Fed, Appx. 678 (9th Cir. 2013); Penguin Group (USA) Inc. v Steinbeck, 537 F.3d 193, 196 (2d Cir. 2008), cert. denied, 129 S. Ct. 2383 (2009); Milne v Stephen Slesinger, Inc., 430 F.3d 1036, 1039 (9th Cir. 2005). See e.g. L.P. Loren, "Renegotiating the Copyright Deal in the Shadow of the Inalienable Right to Terminate" (2010) 62 Fla.L.Rev. 1329; P. Menell and D. Nimmer, "Judicial Resistance to Copyright's Inalienable Right to Terminate Transfers" (2010) 33 Columbia Journal of Law \& the Arts 227. 
Thus, authors' ability to recapture copyright rights has, in practice, been narrowly limited. ${ }^{50}$

Also in the 1976 Act, Congress narrowed the circumstances under which an independent contractor's work could be deemed a work made for hire, legally authored by the creator's employer. Under the current copyright act, works created by employees are works made for hire. Works created by independent contractors, however, can be works made for hire only if the creator signs a work made for hire contract. ${ }^{51}$ That hasn't prevented courts from concluding that works created by individuals who are not treated as employees for the purposes of labour and tax laws should nonetheless be deemed to be employee-created works made for hire, ${ }^{52}$ or that works created by independent contractors who have not signed a work made for hire agreement should be considered to have been authored by the entity that paid for their creation, because that entity's decision-making authority made it the "dominant author" of the work. ${ }^{53}$

Even when the courts construe the statute in authors' favour, moreover, those interpretations have little practical effect on authors' opportunities to control or earn money from their works. In 1993, freelance journalists filed suit against the New York Times, claiming that the Times' licensing of their contributions to electronic and online databases infringed their reproduction, distribution and public display rights. Their initial permission to the Times to print their articles in its newspaper, they insisted, did not allow the Times to resell those articles to electronic database services. The Times argued that a privilege in the statute permitting the publisher of a collective work to reprint contributions to the collective work only as "part of the collective work, any revision of that collective work, or any later collective work in the same series", 54 authorised it to license full issues of its newspaper to digital publishers. The trial court

50 Nor do copyright owners appear to be willing to allow the new or enhanced copyright rights they are seeking to be subject to comparable recapture provisions. Congress is currently considering the CLASSICS Act, a Bill that would establish an entitlement to royalties for the digital transmission of sound recordings that were recorded before US law extended copyright protection to sound recordings. See S. 2334, title 2, 115th Cong. (2018). Although the Bill is described by the recording industry association as a measure to "finally ensure that musicians and vocalists who made those timeless songs finally get their due", see Recording Industry Association of America, "Press Release: Historic Coalition of 213 Musical Artists Calls on Congress to Pass CLASSICS Act, Fix the 'Pre-1972' Loophole for Legacy Artists", 13 February 2018, available at <https:/www.riaa.com/historiccoalition-213-musical-artists-calls-congress-pass-classics-act-fix-pre-1972-loophole-legacy-artists/>, it includes no provisions that would allow the original authors of the sound recordings to recapture the ownership of rights they assigned to record labels.

5117 USC $\S \S 101,201$. See Community for Creative Non Violence v Reid, 490 US 730 (1989). In addition to imposing the requirement of a signed writing, section 101 limits the category of commissioned works made for hire to nine specific subject matter categories. See United States Copyright Office, Circular No. 9: Works Made for Hire (2012), available at <https://www.copyright.gov/circs/circ09.pdf>.

52 See e.g. JustMed v Byce, 600 F.3d 1118 (9th Cir. 2010); JAH IP Holdings v Mascio, 2014 US Dist LEXIS 16246 (D. Colo. 2014).

53 See 16 Casa Duse v Merkin, 791 F.3d 247, 260 (2d Cir. 2015).

5417 USC \& 201(c). 
agreed. ${ }^{55}$ In 2001, the US Supreme Court concluded that the purpose of the statutory privilege was to protect authors' abilities to license their works to other publishers, while enabling the publisher of the initial collective work to print revised editions without again securing permission from every contributor. That purpose would be frustrated if the publishers could license the individual contributions to electronic databases. ${ }^{56}$

In response to the Supreme Court's ruling, the New York Times announced that rather than compensating 27,000 freelance authors for the unauthorised licensing of their works to digital databases, it would instead permit individual authors to request that the Times continue to make all their works digitally available, without any additional payment, on the condition that the authors release all legal claims against the Times and its database licensees. Otherwise, the newspaper would purge all of those freelancers' contributions from its database. ${ }^{57}$ Further, in response to the lawsuit, the New York Times and other large publishers insisted, going forward, that all freelance journalists sign work made for hire or all rights contracts authorising publishers to exploit the works in future as well as existing media for no additional payment. ${ }^{58}$ As Maureen O'Rourke noted: "Although the holding in the case ostensibly gave freelancers a bargaining chip, a lack of bargaining power precludes their obtaining additional consideration for licensing their judicially vindicated rights." 59

Nor have authors outside of the US fared significantly better. Recent studies of the effectiveness of copyright law reforms in the EU designed to improve the lot of creators have concluded that the reforms enacted so far have been ineffective, primarily because authors lack the bargaining power to take advantage of them. ${ }^{60}$

55 Tasini v NY Times, 972 F. Supp. 804 (SDNY 2007), rev'd 206 F.3d 161 (2d Cir. 2000), aff'd 533 U.S. 483 (2001).

${ }^{56}$ NY Times $v$ Tasini, 533 U.S. 483, 499-506 (2001).

${ }^{57}$ See F. Barringer, "Freelancers Suing Again on Copyright", New York Times, 6 July 2001, available at $<$ https://www.nytimes.com/2001/07/06/business/freelancers-suing-again-on-copyright.html>:

The Times's current offer to freelancers - about 27,000 are affected, the newspaper estimates - allows them to request that their material remain available electronically. It contains a provision that "should you opt to have your work restored, you agree that you will not be compensated and that you will release The Times from any claims relating to your work appearing in electronic archives such as Nexis."

Any request must cover all of a freelancer's contributions to The Times; no freelancers can pick and choose how much of their work can remain available.

(ibid.). See "Tasini v The New York Times: A Note on the Consequences", 2 Complete Review Quarterly \#3, August 2001, available at $<$ http://www.complete-review.com/quarterly/vol2/issue3/tasini.htm>.

${ }^{58}$ See O'Rourke, "Bargaining in the Shadow", pp. 605-13.

${ }^{59}$ Ibid., at p. 606 .

${ }^{60}$ See e.g. J.C. Ginsburg and P. Sirinelli, "Private International Law Aspects of Authors' Contracts: The Dutch and French Examples" (2015) 39 Columbia Journal of Law \& the Arts 171; S. Dusollier, C. Ker, M. Iglesias and Y. Smith, "Contractual Arrangements Applicable to Creators: Law and Practice of Selected Member States", study commissioned by the European Parliament Directorate-General for Internal Policies (2014), available at <http://www.cross-innovation.eu/wp-content/uploads/2014/03/ IPOL-JURI_ET2014493041_EN.pdf>; Europe Economics IViR, "Remuneration of Authors of Books 
Too often, copyright scholars' work neglects questions of money. Even when we focus on authors' compensation, we don't always pay attention to whether the money actually makes its way into creators' pockets. Recently, we've been asking collecting societies to do the hard work of managing remuneration for many small-change uses. ${ }^{61} \mathrm{We}$ 've learned that collecting money is easy, but figuring out how to divide it among worthy claimants is really hard. ${ }^{62}$ The statutory, regulatory, and contractual provisions that authorise collective licensing call for the revenues to be distributed to creators and other rights holders, but the mechanisms that we use for deciding how to allocate and pay them are at best imperfect ${ }^{63}$ and often deeply flawed. ${ }^{64}$ Collecting societies are themselves intermediaries who will seek to protect their own positions in the copyright food chain. ${ }^{65}$ We know that there are some collecting entities that pay at least a share of their receipts directly to creators. There are others who pay owners, and rely on the owners to pass the creators' share on. Others dole out the money to organisations that represent creators and task those organisations with figuring out whether and how to distribute the funds to their members. Still others hold the money in an interest-bearing account until prospective claimants can agree with each other on who receives what share, and divide the money up according to their agreement. There are still others who don't disburse the royalties at all - they use the money to pay administrative costs and fund good works. ${ }^{66}$

and Scientific Journals, Translators, Journalists and Visual Artists for the Use of Their Works", study prepared for the European Commission (2016), available at $<$ https://www.ivir.nl/publicaties/download/ remuneration_of_authors_final_report.pdf $>$.

61 See A. Katz, "Copyright Collectives: Good Solution but for Which Problem" in R.C. Dreyfuss, D. Zimmerman and H. First (eds.), Working Within the Boundaries of Intellectual Property: Innovation Policy for the Knowledge Society (New York 2010); see e.g. Music Modernization Act, H.R. 5447, 115th Cong. $\S 102$ (2018) (establishing a new music publisher-owned collective to receive and distribute royalties for a new statutory blanket license for the reproduction of musical compositions in the course of digital streaming). See generally D. Gervais (ed.), Collective Management of Copyright and Related Rights, 3rd ed. (Frederick 2016).

62 See e.g. W. Fisher III, Promises to Keep: Technology, Law \& the Future of Entertainment (Stanford, CA 2004), 207-36; D. Gervais, (Re)structuring Copyright: A Comprehensive Path to International Copyright Reform (Cheltenham 2017), 238-56; European Commission, "Directive on Collective Management of Copyright", 4 February 2014, available at <http://ec.europa.eu/internal_market/copyright/management/>; European Commission Staff Working Document Impact Assessment Accompanying the Document Proposal for a Directive of the European Parliament and of the Council on collective management of copyright and related rights and multi-territorial licensing of rights in musical works for online uses in the internal market 19-29, 11 July 2012, available at $<$ http://eur-lex.europa.eu/legal-content/EN/TXT/PDF/?uri=CELEX:52012SC0204\& from=EN > (hereinafter "Commission Staff Working Document").

63 See e.g. Litman, "Real Copyright Reform", p. 50 and n. 229.

64 See e.g. Copyright Royalty Board New Developments, 10 March 2017, available at <https://www.crb. gov/> (announcing suspension of royalty distribution proceedings required by 17 USC $\S 1007$ ); Commission Staff Working Document, pp. 15-29.

65 See J. Band and B. Butler, "Some Cautionary Tales about Collective Licensing" (2013) 21 Michigan State International Law Review 687; see e.g. M. Long, "Publishers Raise New Concerns over SGAE Practices", IQ Magazine, 11 June 2018, available at <https://www.iq-mag.net/2018/06/publishersnew-concerns-sgae-practices/\#.Wx_5t1Mvw74>.

66 See e.g. H. Wijminga, W. Klomp, M. van der Jagt and J. Poort, "World Intellectual Property Association International Survey on Private Copying: Law and Practice 2016" (2017), available at $<$ http://www.wipo.int/edocs/pubdocs/en/wipo_pub_1037_2017.pdf>. 
Most legal scholars don't spend much attention examining this problem, or trying to ascertain what mechanisms different collecting entities use for deciding how to disburse the money they collect. It's as if, once we've provided that consumers and users must buy a ticket in order to enjoy a copyrighted work, we're done. There may be some policy justification for charging fees as a purely expressive exercise, so that users will understand that enjoyment of a copyrighted work has commercial value. It's wasteful, in the sense that some members of an author's audience will miss encountering the work because they can't afford or don't want to pay the ticket price, but we may make that choice nonetheless to send the message that enjoying works of authorship should not be free. ${ }^{67}$ If that's why we're doing it, though, we should say so. If, on the other hand, our purported reason for levying the charge is to put money into creators' pockets, it might be a good idea to look to see how much of it actually gets there. At least in the US, that question hasn't been the focus of much legal scholarship. ${ }^{68}$

Some copyright scholars have begun to ask the question whether and when creators respond to the rewards promised by copyright, and to try to harness the insights of disciplines other than the law - economics, psychology, neurology, history - to see whether it might be possible to come up with answers. ${ }^{69}$ It's difficult, though, to evaluate whether the answers to that question have real-world significance without knowing whether and under what circumstances creators will actually collect those rewards.

If I'm right that most of us have given up on close scrutiny of author compensation because we suspect that it's a hopeless inquiry, this may be a good time to re-examine that impulse. That, however, would require us to confront the questions we no longer ask and the features of the copyright system that we seldom notice, because we've grown inured to the

${ }^{67}$ Cf. J.C. Ginsburg, "Fair Use for Free, or Permitted-but-Paid?" (2015) 29 Berkeley Tech.L.J. 1383.

68 But see P. DiCola, "Money From Music: Survey Evidence on Musicians' Revenue and Lessons About Copyright Incentives" (2013) 55 ACJ 301. There are a number of recent economic and legal studies from Europe, with discouraging conclusions. See e.g. M. Kretschmer, "Copyright and Contracts: Regulating Creator Contracts: The State of the Art and a Research Agenda" (2010) 18 J.Intell.Prop. L. 141; R. Towse, "Economics of Copyright Collecting Societies and Digital Rights: Is there a Case for a Centralised Digital Copyright Exchange?" (2012) 9 Review of Economic Research on Copyright Issues 3; C. Handke and R. Towse, "Economics of Copyright Collecting Societies" (2007) 38 International Review of Intellectual Property \& Competition Law 937; R. Towse, "Copyright and Artists: A View From Cultural Economics" (2006) 20 Journal Economic Surveys 567; Europe Economics IViR, "Remuneration of Authors"; M. Kretschmer, "Private Copying and Fair Compensation: An Empirical Study of Copyright Levies in Europe" (2011), available at $<$ https://assets.publishing.service.gov.uk/government/uploads/system/uploads/attachment_data/file/ 310183/ipresearch-faircomp-201110.pdf > .

69 E.g. G. Lunney, Copyright's Excess: Money and Music in the US Recording Industry (Cambridge 2018); C. Sprigman, "Copyright and Creative Incentives: What We Know (and Don't)" (2017) 55 Hous.L.R. 451; R. Tushnet, "Economies of Desire: Fair Use and Marketplace Assumptions" (2009) 51 William \& Mary Law Review 513; D. Zimmerman, "Copyright As Incentives: Did We Just Imagine That?" (2010) 12 Theo Inq Law 29; M. Senftleben, "Copyright, Creators, \& Society's Need for Autonomous Art - the Blessing and Curse of Monetary Incentives" (2017) in Giblin and Weatherall, What If We Could Reimagine Copyright?, p. 25. See also CREATe Copyright Research Centre at the University of Glasgow, Copyright Evidence Wiki, available at $<\mathrm{http}: / /$ www.copyrightevidence.org/evidence-wiki/index.php/Copyright_Evidence > (cataloguing empirical studies). 
ways that the copyright system fails to deliver on the promises of copyright theory.

\section{COPYRIGHT AND PROPERTY}

In the rest of this essay, I'll argue that one reason we talk less than we should about how the copyright system commonly fails to reward creators is that our assumptions about legal property rights distort our perceptions of the way the copyright laws operate. Copyright experts take a lot for granted about the way the copyright system works and is supposed to work. Copyright is a property right. We're lawyers. The legal characteristics of property rights are basic building blocks of our legal education.

One element of legal property rights is control, and most of the debates over treating copyright as a form of property have focused on the control that a property owner is able or should be able to exercise. ${ }^{70}$ Control is an important aspect of property, but it isn't the only or even the most important aspect. After all, we have lots of different ways to give an individual legal control over something without giving her a property right.

What makes property rights special is that they are alienable. ${ }^{71}$ Treating something as property makes it easier to sell. We define a right as a property right to encourage its transfer. ${ }^{72}$ This intrinsic feature of legal property is something that it's easy for lawyers to take for granted. What makes it possible for publishers, record labels, and other intermediaries to behave the way they've been behaving is that the powers conferred by a copyright belong to the copyright owner rather than the author. ${ }^{73}$ That strikes nonlawyers as odd, but it's second nature to us. Our copyright system empowers publishers and record labels to structure licensing deals for their own benefit, since they own the copyrights, and set the terms and conditions for copyright licenses.

Because we're lawyers, we know that the grantee of a property right stands in the shoes of the grantor and is entitled to exercise the powers embodied in the property right. We assume that the original property owner has had the opportunity to extract compensation for the value of the right, because that's just how property rights work. Indeed, copyright lawyers and scholars sometimes use the words "author" and "copyright

70 See e.g. L. Lessig, Free Culture (New York 2004), 83-173; Patry, Moral Panics and the Copyright Wars, pp. 109-32; S. Aistars, D. Hartline and M. Schultz, "Copyright Principles and Priorities to Foster a Creative Digital Marketplace" (2016) 23 Geo. Mason L.Rev. 769; M. Grynberg, "Property Is a Two-Way Street: Personal Copyright Use and Implied Authorization" (2010) 79 Fordham L. Rev. 435; R.P. Merges, "The Concept of Property in the Digital Era" (2008) 45 Hous.L.R. 1239; A. Mossoff, "Is Copyright Property?" (2005) 42 San Diego L.Rev. 29.

71 Accord, Ginsburg, "The Place of the Author in Copyright", pp. 66-67.

72 See e.g. J. Litman, "Information Privacy/Information Property" (2000) 52 Stan.L.Rev. 1283, at 1295301.

73 See e.g. Fisher, Promises to Keep, pp. 47-70, 204-05; Bently, "Between a Rock and a Hard Place", pp. 15-21; Kretschmer, "Does Copyright Law Matter?”, pp. 32-33. 
owner" interchangeably, treating them as synonyms. ${ }^{74}$ After all, the author is the initial copyright owner, and the person to whom she transfers those rights is entitled to step into her shoes. For most purposes, in the eyes of the law, the owner is the author. ${ }^{75}$

We could take a more nuanced look at how legal copyright property rights actually behave in the world. We should examine our view of legal property to identify the things that our assumptions may prevent us from seeing.

\section{The Dawes Act and the Statute of AnNe}

I'm going to take a short detour to tell a story that, at least at first, isn't going to seem as if it has any bearing on copyright law. It begins about 400 years ago. In the sixteenth and seventeenth centuries, European colonists sailed to North America to develop new territories in the names of their sovereigns. ${ }^{76}$

Unfortunately, the new land already had occupants who had lived on that land for centuries. The European settlers moved in anyway. Sometimes, it was possible for the Europeans and the indigenous tribes to coexist, at least initially; in other situations, though, the indigenous Indian tribes occupied area that the Europeans wanted to control. ${ }^{77}$ The Indians weren't white, weren't Christian and weren't farmers. They weren't using the land for what the Europeans believed to be the best and highest purpose. ${ }^{78}$ Some of the European settlements felt little compunction about seizing the land from its occupants. Violence ensued. ${ }^{79}$

Eventually, after enough people had been killed and enough property had been damaged, the settlements and the tribes reached agreements, dividing

${ }^{74}$ See e.g. J.C. Ginsburg, "Copyright Use and Excuse on the Internet" (2000) 24 Colum.-VLA J.L. \& Arts 1, at 41; R. Oman, "Going Back to First Principles: The Exclusive Rights of Authors Reborn" (2008) 8 Journal of High Technology Law 169, at 176-77, 180.

75 See e.g. B. Viswanathan and A. Mossoff, "Open-Access Mandates and the Seductively False Promise of 'Free', Center for the Protection of Intellectual Property Briefing Paper 4, April 2017, available at $<\mathrm{http} / / /$ apo.org.au/node/93506>. Moral rights, of course, are an important exception to this rule. Even in countries with robust moral rights protection, however, those rights appear to have negligible economic value and restrain the exploitation of copyrighted works only in extreme cases.

76 See generally R.T. Anderson, B. Berger, S. Krakoff and P.E. Frickey, American Indian Law: Cases and Commentary, 3rd ed. (St. Paul 2015), 22-25.

77 See generally e.g. N.J. Newton (ed.), Cohen's Handbook of Federal Indian Law: 2005 Edition (Newark 2005).

${ }^{78}$ See ibid.; E. Kades, "The Dark Side of Efficiency: Johnson $v$ M'Intosh and the Expropriation of American Indian Lands" (2000) 148 U.Pa.L.Rev. 1065, at 1076-77.

79 See B. Berger, "Red: Racism and the American Indian" (2009) 56 UCLA Law Review 591, at 603-07. See e.g. E.A. Schmidt, The Divided Dominion: Social Conflict and Indian Hatred in Early Virginia Boulder, CO (2014), 45-61 (Anglo-Powhatan wars between English settlers in the Virginia Colony and the Powhatan tribe); S. Feeley, "'Before Long to be Good Friends:' Diplomatic Perspectives of the Tuscarora War" in M. LeMaster and B.J. Wood (eds.), Creating and Contesting Carolina (Columbia 2013), 140 (Tuscarora war between Tuscarora tribe and British, German and Dutch settlers in North Carolina); E. Haefeli, "Kieft's War and the Cultures of Violence in Colonial America" in M.A. Bellesiles (ed.), Lethal Imagination: Violence and Brutality in American History (New York 1999), 17 (war between Dutch settlers in the New Netherland colony and the Lenape tribe). 
up the disputed territory between them. ${ }^{80}$ Those agreements, though, turned out to be unstable. The European-Americans kept seeking to expand their territory. Over the next 200 or so years, they used money, persuasion, threats, citizen violence, and military force to convince or compel Indian tribes to relocate westward to more remote and less desirable land. ${ }^{81}$ Along the way, more violence ensued. ${ }^{82}$ The American army was busy conducting one or another war with Indian tribes for most of the nineteenth century. ${ }^{83}$

American courts concluded that Indians had an enforceable legal right to occupy tribal land, but that they didn't actually own it. ${ }^{84}$ The US federal Government came under immense pressure to open Indian land for settlement by white European-Americans. ${ }^{85}$ It tried to use the tools at its disposal (money and soldiers) to move the tribes out of the way of white homesteaders. Indian tribes who had agreed to resettle west of the Mississippi river, only to be asked to move again, were increasingly reluctant to consent to be uprooted. ${ }^{86}$ Besides, the Government was running out of surplus land. ${ }^{87}$ Yet more violence followed. ${ }^{88}$

White Americans resented the tribes' control of land that they believed should by rights be available to them. They pursued a variety of devices, many of them unlawful, to wrest control of the land from the tribes. ${ }^{89}$

What ended up doing the trick was a series of statutes of which the most famous was the Dawes Act, also known as the General Allotment Act of 1887. ${ }^{90}$ Instead of taking the land away from the tribes, the Dawes Act gave title to the tribal land to individual Indians. The Act divided the vast tracts of territory controlled by Indian tribes into many 160-acre plots, and awarded each plot to an individual Indian head of household,

80 See S. Banner, How the Indians Lost Their Land (Cambridge, MA 2005), 85-111.

81 See e.g. Anderson et al., American Indian Law, p. 50; Banner, How the Indians Lost their Land, pp. 191-227.

82 See e.g. Banner, How the Indians Lost Their Land, pp. 121-29; Newton, Cohen's Handbook, pp. 3536, 39-40, 44; A. Deboe, A History of the Indians of the United States (Norman, OK 1970), 101-16; A. Deboe, The Road to Disappearance: A History of the Creek Indians (Norman, OK 1966), $72-107$.

83 See Banner, How the Indians Lost Their Land, pp. 237-47; see e.g. Newton, Cohen's Handbook, pp. 51-54, 71; E.A. Schwartz, The Rogue River Indian War and Its Aftermath: 1859-1980 (Norman, OK 1997), 69-160.

84 E.g. Johnson's Lessee v M'Intosh, 21 US 543 (1923); see Banner, How the Indians Lost Their Land, pp. 15090; L.G. Robinson, "The Judicial Conquest of Native America: The Story of Johnson v M'Intosh" in C. Goldberg, K.K. Washburn and P.P. Frickey (eds.), Indian Law Stories (New York 2011), 29.

85 See Banner, How the Indians Lost Their Land, pp. 195-226.

86 See ibid., at pp. 197-201, 212-17, 222-26; Newton, Cohen's Handbook, pp. 51-54, 73.

87 See Banner, How the Indians Lost Their Land, pp. 228-36.

88 See e.g. Anderson et al., American Indian Law, pp. 74-77; Newton, Cohen's Handbook, pp. 70-71, 73.

89 See Banner, How the Indians Lost Their Land, pp. 214-27, 237-45.

90 General Allotment Act of 8 February 1887, 24 Stat. 388, ch. 119. See also Act for the Protection of the People of Indian Territory, Pub. L. 55-515, 30 Stat. 495 (1898) (“Curtis Act”); Dawes Act Amendment of 1891, 26 Stat. 794 (1891); General Allotment Act Amendment of 1906, Pub. L. 59-149, 34 Stat. 182 (1906) ("Burke Act"); Act Authorizing the Secretary of the Interior to allot homesteads to the natives of Alaska, Pub. L. 59-171, 34 Stat. 197 (1906). For historical background on the allotment policy and a brief description of initial allotment efforts preceding the Dawes Act, see generally Newton, Cohen's Handbook, pp. 66-69, 75-78. 
in trust for a short period and then in fee simple. During the trust period, the Indian owners were permitted to lease the plot to white Americans. After the trust period expired, the Indian household that owned the land was free to sell it to any buyer. Any unallocated plots were deemed "surplus land", and were purchased from the tribe by the federal Government and made available for sale to non-Indians. At the time, I'm sure that some of the supporters of the law believed it would empower individual Indians to vest them with ownership of a plot of land; other supporters, though, had more cynical motives. In any event, to the extent that one purpose of the statutes was to encourage the transfer of land from Indian tribes to white American citizens, it was a stunning success. Very quickly, the majority of the land occupied by Indian tribes passed out of Indian hands through sales to non-Indians. The winners were white settlers and land speculators; the Indians ended up both impoverished and often displaced. ${ }^{91}$

I want to draw a couple of parallels from that story to a statute that copyright lawyers are more familiar with. This story starts at about the same time. In the sixteenth and seventeenth centuries, the members of the Stationers' Company had a monopoly on publishing, augmented by a naked horizontal restraint of trade among the members. ${ }^{92}$ After more than a century controlling the business of publishing, the Stationers surely felt entitled to continue to exercise that control. They had, after all, invested significant money and efforts into printing and selling their texts. When Parliament declined to re-enact the licensing act that gave the members of the Stationers company their printing monopoly, the Stationers engaged in strenuous lobbying to persuade the Government to restore it. ${ }^{93}$

I don't want to simplify the complex set of considerations that went into enacting the Statute of Anne, ${ }^{94}$ or to minimise the provisions included for the protection of universities, readers and consumers, ${ }^{95}$ or to suggest that

91 Banner, How the Indians Lost Their Land, pp. 257-93; see J.V. Royster, "The Legacy of Allotment" (1995) 27 Ariz.St.L.J. 1, at 10-14. In 1934, Congress repudiated the allotment program. The Indian Reorganization Act of 1934 prohibited further allotment of Indian land and sought to return to the tribes some portion of the 90 million acres of Indian land that had passed into non-Indian ownership. Indian Reorganization Act, Pub. L. No. 73-383, 48 Stat. 984 (1934) (codified as amended at 25 U.S.C. $\S \S 461-$ 479 (1976). See Blackfeet Tribe of Indians v State of Montana, 729 F.2d 1192 (9th Cir. 1984) (en banc), aff'd 471 US 759 (1985).

92 See e.g. L.R. Patterson, Copyright in Historical Perspective (Nashville 1968), 28-77; I. Gadd, "The Stationers Company in England before 1710" in I. Alexander and H.T. Gomez-Arostegui (eds.), Research Handbook on the History of Copyright Law (Cheltenham 2018), 81, 88-92.

93 See C. Blagden, The Stationers Company: A History 1403-1959 (London 1960), 153-77; R. Deazley, On the Origin of the Right to Copy (Oxford 2004), 1-50; I. Alexander, "All Change for the Digital Economy: Copyright and Business Models in the Early Eighteenth Century" (2010) 25 Berkeley Tech.L.J. 1351; Gadd, "The Stationers Company in England before 1710", pp. 92-95.

94 Statute of Anne, 8. Anne, c. 19 (1710). See e.g. Deazley, On the Origin of the Right to Copy, pp. 31-50; Alexander, "All Change for the Digital Economy", pp. 1354-62; H.T. Gomez-Arostegui, "The Untold Story of the First Copyright Suit under the Statute of Anne in 1710" (2010) 25 Berkeley Tech.L.J. 1247, at 1251-58; J. Litman, "Readers' Copyright" (2011) 58 J. Copyright Soc'y U.S.A. 325, at 332-35.

95 See A. Katz, "Copyright, Exhaustion, and the Role of Libraries in the Ecosystem of Knowledge" (2016) 13 I/S Journal of Law \& Policy for the Information Society 81, at 84-86; Litman, "Readers' Copyright", pp. 333-35. 
some of the law's supporters didn't believe that it would empower authors. Whatever the intention, the law ended up working out pretty well for the members of the Stationers' company. By establishing an assignable property right for authors and their assigns, the law encouraged authors to convey their copyrights to printers and publishers (who, after all, were the folks with the printing presses), where they have stayed pretty much for the next 300 years. ${ }^{96}$

The rest of the world followed that model.${ }^{97}$ In almost every country, authors receive copyright protection as an initial matter, but those copyrights are transferred to and then owned and controlled by publishers and other intermediaries. ${ }^{98}$ In the US, where capitalism is both our economic system and our dominant religion, courts were especially eager to conclude that authors had conveyed their copyrights to publishers, even in the absence of any evidence, and that inclination has persisted. ${ }^{99}$ When it didn't work to simply presume that the copyright had been transferred, our courts invented the work made for hire doctrine out of whole cloth. ${ }^{100}$

The moral of both of these stories is that deeming a resource to be a property right is often an extremely effective way to gain control of that resource, especially when you don't have control of it at the outset. When the law transforms something that was not formerly property into a property right, the accompanying alienability will cause control of it to flow to those with the most bargaining power. If you are looking to get your hands on some arable land or to regain your control of the printing of texts, creating new property rights turns out to be an excellent strategy. Sometimes the original recipient of the property benefits, but not always. Sometimes the world improves as a result; other times it doesn't.

\section{The Wages of Property Rights}

So, here's the upshot: immense sums of money slosh through the current copyright system, but only a tiny share of that money ends up in authors' pockets. By some accounts, that share has been decreasing. We all know that, because, as I said, we live in the world and see the evidence all around us, but we have tended to overlook it when we talk about copyright law reform. Over the past 300 years, we've expanded and extended copyright

\footnotetext{
96 See Patterson, Copyright in Historical Perspective, pp. 143-50, 213-21.

97 See e.g. O. Bracha, "The Adventures of the Statute of Anne in the Land of Unlimited Possibilities: The Life of a Legal Transplant" (2010) 25 Berkeley Tech.L.J. 1427.

98 See J.C. Ginsburg and E. Treppoz, International Copyright Law US and EU Perspectives: Text and Cases (Cheltenham 2015); P. Goldstein and B. Hugenholz, International Copyright, 2nd ed. (Oxford 2010), 244-69; Ginsburg, "The Place of the Author in Copyright", pp. 63-66.

99 See Litman, "What Notice Did", pp. 732-34; see e.g. Bleistein v Donaldson Lithographing Co., 188 U. S. 239, 248-49 (1903); Edward Thompson Co. Am. Law Book Co., 119 F. 217,219 (C.C.S.D.N.Y. 1902); Colliery Eng'r Co. v United Correspondence Schs., 94 F. 152, 153 (C.C.S.D.N.Y. 1899).

100 See C. Fisk, "Authors at Work: The Origins of the Work-for-Hire Doctrine" (2003) 15 Yale J.L. \& Human. 1.
} 
repeatedly, and larded the law up with new licenses and payment obligations. ${ }^{101}$ We've failed, however, to pay enough attention to how - or whether - the intermediaries tasked with distributing the revenues actually disburse them. We don't look inside the black box surrounding the author's conveyance of her rights to a new owner. Because we understand how property rights work, we trust and assume that the profits flowing from copyright expansion redound to the benefit of authors.

But, because we live in the world, we know, or should know, that often they don't. If we believe that that's a problem (and I happen to), we won't be able to figure out how to fix it without a careful examination of what is inside the black box. That means asking some questions that we aren't in the habit of asking, and that copyright owners are not in the habit of answering. ${ }^{102}$

(Let me say, parenthetically, that if we decide that it isn't a problem that authors receive so small a share of the proceeds from their works, the fuss about the so called "value gap" makes even less sense. If we believe that economics and policy support the conclusion that authors' teeny-weeny percentage of the vast sums generated by the enjoyment of works of entertainment and information is the right amount to pay them, it's hard to see any justification for interfering in the negotiations among commercial distributors to dictate which of them gets the largest share of the very substantial remainder.)

If the problem is worth addressing, though, we should have learned by now that it isn't a useful solution to throw more money and control at copyright owners and trust that, this time, they will share a larger part of it with authors.

I want to emphasise the narrow limits of the argument that I'm making. I'm not arguing that the alienability of copyrights is itself the problem, nor that I believe that we could solve it simply by limiting copyright transfers or making rights inalienable. After all, consider Germany. Germany treats copyrights as inalienable, at least formally, ${ }^{103}$ but German authors don't appear to enjoy significant financial advantages over authors from other countries. ${ }^{104}$ I think the role that the alienability of property rights plays in my argument is twofold. First, whenever we have significant disparities

101 See e.g. N.W. Netanel, Copyright's Paradox (Oxford 2008), 54-80.

102 I don't mean to minimise the practical difficulties posed by intermediaries' insistence that contract terms and payments are proprietary information that they are entitled to keep secret. See e.g. P. DiCola and D. Touve, "Licensing in the Shadow of Copyright" (2014) 17 Stanford Technology Law Review 397, at $443-57$.

103 See German Copyright Act $\S \S 29,31$.

104 See e.g. M. Kretschmer and P. Hardwick, "Authors' Earnings from Copyright and Non-Copyright Sources: A Survey of 25,000 British and German Writers" (Dorset 2007), available at https://microsites.bournemouth; Kretschmer, "Does Copyright Law Matter?", pp. 12-15; Senftleben, "Copyright, Creators, \& Society's Need for Autonomous Art", p. 53. See also e.g. Ginsburg and Sirinelli, "Private International Law Aspects of Authors' Contracts" (examining private international law obstacles to implementing author-protective legislation enacted in France and the Netherlands). 
in wealth and bargaining power, the distribution of freely alienable property rights is almost always going to mirror and will often exacerbate those disparities. Second, the legal dogma surrounding property rights, which, as lawyers, we've inhaled since we were students, can keep us from appreciating those disparities. We don't pay enough attention to the use of alienable property rights as a device to allow powerful actors to appropriate valuable items in the control of less powerful actors.

\section{Seeing What We Don't SeE}

Is the problem indeed as intractable at it sometimes seems, or is there something we could do to address it?

Copyright in the twenty-first century is a byzantine legal ecosystem. I believe that there would be real value in our exploring that ecosystem, carefully and from the inside, in order to understand the reasons that it has persistently given creators short shrift. That would involve our taking a painstaking look at the way that authors and copyright owners structure their interactions, to figure out where, if anywhere, an intervention might be effective.

I don't have an easy solution to propose. It's possible, but unlikely, that we could tweak copyright ownership law or revise copyright licensing rules in ways that could significantly improve the world for at least some authors. ${ }^{105}$ Throwing more copyright rights at copyright owners ${ }^{106}$ is unlikely to trickle down to creators - at least unless and until we understand more of the dynamic that results in their getting such a small share of the proceeds from their creations. Adjusting the law to enhance the bargaining power of publishers over platforms or platforms over publishers ${ }^{107}$ isn't

105 See e.g. J.E. Cohen, Configuring the Networked Self (New Haven 2012), 223-66; Gervais, Collective Management of Copyright and Related Rights, pp. 191-215; W. Patry, How to Fix Copyright (Oxford 2011), 177-88; J. Silbey, The Eureka Myth: Creators, Innovators and Everyday Intellectual Property (Stanford 2015), 274-85; Loren, "Renegotiating the Copyright Deal"; R.A. Reese, "Optional Copyright Renewal: Lessons for Designing Copyright Systems, The 38 Annual Horace J. Manges Lecture” (2015) 39 Columbia Journal of Law \& the Arts 145; M. Van Houweling, "Making Copyright Work for Authors Who Write to Be Read" (2015) 38 Columbia Journal of Law \& the Arts 381.

106 See e.g. H.R. 1836, Fair Play Fair Pay Act, 115th Cong. (2017) (giving sound recording copyright owners new exclusive right to perform their sound recordings over AM and FM radio); C. Geiger, O. Bulayenko and G. Frosio, "The Introduction of a Neighbouring Right for Press Publishers at EU Level: The Unneeded (and Unwanted) Reform" (2017) 39 EIPR 202.

107 See e.g. Joint Comments of Amer. Ass'n of Independent Music et. al., U.S. Copyright Office: In re Section 512 Study, Docket No. 2015-7, 31 March 2016, available at <https://www.riaa.com/wp-content/uploads/2016/03/Music-Community-Submission-in-re-DMCA-512-FINAL-7559445.pdf>; J. Chu and T. Marino, "Victims of IP Theft Need Better Protection", The Hill, 12 March 2014, available at $<$ http://thehill.com/opinion/op-ed/200630-victims-of-ip-theft-need-better-protection>; J. Taplin, "Is it Time to Break Up Google?", New York Times, 22 April 2017, available at <https://www.nytimes. com/2017/04/22/opinion/sunday/is-it-time-to-break-up-google.html >; S. Carlisle, "DMCA 'Takedown' Notices: Why 'Takedown' Should Become 'Takedown and Stay Down' and Why It's Good for Everyone", Nova Southeastern University Copyright Office Blog, 23 July 2014, available at <http://copyright.nova.edu/dmca-takedown-notices/>; E. Harmon, "Notice and Stay Down' Is Really Filter Everything", Electronic Frontier Foundation Deeplinks Blog, 21 January 2016, available at <https://www.eff.org/deeplinks/2016/01/notice-and-stay-down-really-filter-everything $>$. 
calculated to make life better for creators. I don't see much promise in any of the pending statutory or treaty proposals currently on the table. It may be that those proposals are the only proposals that have any practical chance of adoption, precisely because Reed Elsevier, Vivendi, Disney or Google won't countenance any new law or treaty that leaves them no better off than the current law. Copyright intermediaries have enough political power to insist on watering down reform proposals until they will be of little actual use to creators, and have recently exercised that power to revise legislative and treaty proposals in their favour. ${ }^{108}$ Over the past 20 years, we've seen several unsuccessful efforts to reform national and international copyright law-making processes to weaken the influence wielded by powerful copyright players. ${ }^{109}$ Such efforts face obstacles that seem insurmountable. The firm hold that copyright intermediaries have on national and international law-making processes, and their current preoccupation with marshalling all available resources to vanquish each other, suggest that realistic opportunities for author-empowering copyright reforms may be scant.

I suspect that we may end up concluding that the more promising proposals are only tangentially related to copyright law. Many creators lack the bargaining power to exercise the rights theoretically afforded to them by current law. ${ }^{110}$ If the pivotal problem is a lack of bargaining power, though, new or enhanced property rights are unlikely to solve it. It is just remotely possible that we might make more headway by attacking the problem from the other end. There may be interventions to address the bargaining power deficit more directly. Catherine Fisk has argued that encouraging authors to engage in collective bargaining may be the most practical solution, even if the price of that bargaining would be the loss of copyright ownership. ${ }^{111} \mathrm{I}$ can imagine requiring the collecting entities that don't currently pay the creators' share of royalties directly to creators to do so from now on. ${ }^{112}$ Some scholars have suggested that self-publishing over the Internet may allow creators to compete directly with intermediaries and to collect a larger share of the proceeds from their works. ${ }^{113}$ My colleague Jeremy Peters has

${ }^{108}$ See e.g. R. Giblin, "Should It Be Copyright's Role to Fill Houses with Books?" in S. Frankel and D. Gervais (eds.), Intellectual Property and Regulation of the Internet: The Nexus with Human and Economic Development (Wellington 2017); M.E. Kaminski, "The Capture of International Intellectual Property Through the US Trade Regime" (2014) 87 S.Cal.L.Rev. 977.

109 See e.g. G. Krikorian and A. Kapczynski (eds.), Access to Knowledge in the Age of Intellectual Property (New York 2010); L. Lessig, Republic, Lost: How Money Corrupts Congress - and a Plan to Stop It (New York 2011).

${ }^{110}$ See e.g. Bently, "Between a Rock and a Hard Place"; Ginsburg and Sirinelli, "Private International Law Aspects of Authors' Contracts"; O'Rourke, "Bargaining in the Shadow".

111 See C. Fisk, "Hollywood Writers and the Gig Economy" (2018) 2017 U.Chi. Legal F. 177.

112 See e.g. Future of Music Coalition, "Principles for Artist Compensation in New Business Models", 2 April 2009, available at $<$ https://www.futureofmusic.org/article/article/principles-artist-compensationnew-business-models $>$.

113 See e.g. J.M. Garon, "Digital Hollywood 2.0: Reimagining Film, Music, Television and Publishing Distribution as a Global Artist Collaborative" (2013) 21 Michigan State International Law Review 563; O'Rourke, "Bargaining in the Shadow", p. 638. 
suggested that we could get a lot of mileage from encouraging or requiring copyright owners to adopt generally recognised accounting standards, along with mandated, publicly-available annual audits. I suspect we might get somewhere by imposing labelling rules that required purveyors of copies of or access to copyrighted works to disclose the percentage of the purchase price that will be paid directly to creators of the work. ${ }^{114}$ It might be useful to set up and fund government or non-profit organisations tasked with educating and supporting creators in appreciating and enforcing their current legal rights against the entities to which they've transferred their copyrights. ${ }^{115}$

None of these approaches comes from the copyright scholar's usual toolbox. There's value, though, in exploring the copyright system from unaccustomed vantage points. If nothing else, it can help us to appreciate what we tend not to see and why we don't see it.

${ }^{114}$ Cf. R. Giblin, "The Author Made 3p from the Sale of this Book", The Author's Interest Blog, 3 April 2018, available at <https://authorsinterest.org/2018/04/03/more-on-fair-trade-for-authors/>.

115 E.g. O’Rourke, "Bargaining in the Shadow", pp. 637-38. See generally Bowker, "Self-Publishing in the United States 2010-15" (2015), available at <http://media.bowker.com/documents/bowker-selfpublishing-report2015.pdf>; R. Shapiro and S. Aneja, "Unlocking the Gates: America's New Creative Economy" (2018), available at <http://www.recreatecoalition.org/wp-content/uploads/2018/02/ ReCreate-Creative-Economy-Study-Report.pdf $>$. 